\title{
Antioxidant Activity and Hepatoprotective Potential of Piper chaba Roots against Paracetamol-Induced Liver Injury
}

\author{
Samina Yesmin, Ronok Zahan, Md. Monjad Hossain, A. B. M. Atiqur Rahman, \\ Alam Khan, Mir Imam Ibne Wahed, Tarannum Naz* \\ Department of Pharmacy, Faculty of Science, University of Rajshahi, Rajshahi, Bangladesh \\ Email: *taranazbd@gmail.com
}

How to cite this paper: Yesmin, S., Zahan, R., Hossain, Md.M., Rahman, A.B.M.A., Khan, A., Wahed, M.I.I. and Naz, T. (2019) Antioxidant Activity and Hepatoprotective Potential of Piper chaba Roots against Paracetamol-Induced Liver Injury. Pharmacology \& Pharmacy, 10, 484-497.

https://doi.org/10.4236/pp.2019.1011040

Received: September 14, 2019

Accepted: November 8, 2019

Published: November 11, 2019

Copyright $\odot 2019$ by author(s) and Scientific Research Publishing Inc. This work is licensed under the Creative Commons Attribution International License (CC BY 4.0).

http://creativecommons.org/licenses/by/4.0/

\begin{abstract}
Paracetamol induces oxidative damage of liver and hepatotoxicity continues to be among the main threats of public health. The present study evaluated the antioxidant and hepatoprotective activities of $P$. chaba roots. Hepatoprotective effects were demonstrated by significant alteration of serum biomarker enzymes and antioxidant enzymes. Co-administration of $P$. chaba extract to paracetamol-induced rats resulted in a partial recovery in the serum biochemical parameters (SGOT, SGPT, ALP and Bilirubin). However, ethanolic extract of Piper chaba at lower dose (200 $\mathrm{mg} / \mathrm{kg}$ b.w.) was more effective than the higher dose $400 \mathrm{mg} / \mathrm{kg}$ b.w. in reducing serum dysfunction biomarker enzymes. The histopathological studies of liver tissues also showed better hepatoprotective activity of Piper chaba roots at the lower dose $(200 \mathrm{mg} / \mathrm{kg}$ b.w.). Paracetamol induced hepatotoxicity in rats resulted in increase of antioxidant enzyme activities such as catalase, super oxide dismutase. The scavenging activity of $P$. chaba extract was moderate when compared with standard catechin and the $\mathrm{IC}_{50}$ values of $P$. chaba and standard catechin were $1.563 \pm 0.70$ and $3.125 \pm 0.676$, respectively in DPPH radical scavenging assay. The total antioxidant potential of $P$. chaba was concentration dependent and revealed promising antioxidant activity as compared to the reference standard catechin. At a concentration of $100 \mu \mathrm{g} / \mathrm{mL}$ the absorbance of $P$. chaba extract and catechin were 0.430 and 0.746 respectively. The research result indicated that $P$. chaba extract has protective effects on paracetamol induced oxidative stress and liver damage.
\end{abstract}

\section{Keywords}

Piper chaba, Antioxidant, Hepatoprotection, Oxidative Damage 


\section{Introduction}

In the UK between 2000-2008, there were 90 - 155 deaths from paracetamol poisoning every year and the most common agent of intentional self-harm [1]. It is also the most common cause of acute liver failure (ALF). Children and pregnant woman are more susceptible to paracetamol induced toxicity. Paracetamol is primarily metabolized by glucoronidation and sulphation [2]. Approximately $55 \%$ and $30 \%$ of paracetamol is normally excreted in urine as glucoronide and sulphate conjugates, respectively. A small fraction of paracetamol is also metabolized by the microsomal cytochrome P450 (CYP) containing mixed-function oxidase system to reactive intermediates. Evidence has been presented that $\mathrm{N}$ acetyl-p-benzo-quinone (NAPQI) is the reactive eletrophilic intermediate formed by the iso-enzyme system CYP2E1 that is responsible for the observed hepatotoxicity after excess intake of paracetamol [3].

The hepatotoxic effect of paracetamol and some chemical agents is reported to be associated with the generation of reactive oxygen species (ROS). These ROS are reported to be associated with lipid peroxidation in the liver [4]. Liver cell injury is severely associated with oxidative stress (OS) caused by free radicals. Oxidative stress (OS) represents an imbalance between the production and manifestation of reactive oxygen species (ROS) and a biological system's ability to readily detoxify the reactive intermediates or to repair the resulting damage. Disturbances in normal redox state of tissues can cause toxic effects through the production of reactive oxygen species (ROS), such as peroxides and free radicals that damage all components of the cell. Some of the ROS (such as superoxide) can be converted by oxido-reduction reactions into more aggressive radical species that can cause extensive cellular damage [5].

Piper species are widely distributed in the tropical and subtropical regions of the world. The plant Piper chaba Hunter (piperaceae) is a climbing, flowering vine, glabrous shrub available in various part of India, and other warmer regions of Asia including Malaysia in various parts of India and Malay Islands, Indonesia, Singapore and Sri Lanka [6]. It is called Chui Jhal or Choi Jhal in the southwestern districts of Bangladesh, Tripura (India) and West Bengal (India) $P$. chaba is found. In Bangladesh it is grown in plenty in the southern part particularly in Jessore, Khulna, Satkhira and Bagerhat. Roots of $P$. chaba have been used for dyspepsia, carminative, colic and gastralgia [7]. The fruits are traditionally used in asthma, bronchitis, fever, inflammation, piles, pain in abdomen and anus [8]. Previous studies on stem bark of $P$. chaba yielded piperine and its analogs, a piperine analog, piperine dimer chabamide, lignin, and sterols [9]. The amide from $P$. chaba has been found significantly inhibit ethanol and indomethacin induced gastric lesions [10]. Extracts and compounds from fruits of $P$. chaba have shown hepatoprotective effect on D-galactosamine/lipopolysaccharide-induced liver injury in mice [11] [12]. The plant also have antibacterial, antifungal, and cytotoxic activities [9].

Currently, some synthetic antioxidants (e.g. BHT, BHA, phenolic antioxidants 
etc.) are used to prevent free radical damage. Although, these synthetic antioxidants are carcinogenic in nature and consumer attention has shifted the attention of manufactures from synthetic to natural antioxidants [13]. The use of natural antioxidants in food, cosmetic and therapeutic purpose would be promising alternative for synthetic antioxidants in respect of low cost, highly compatible with dietary intake and no harmful effects inside the human body. Many antioxidant compounds, naturally occurring in plant sources have been identified as free radical or active oxygen scavengers [14]. Research on herbal drugs could replace the chemical ones. Therefore, considering valuable traditional medicinal uses of roots of $P$. chaba, present study was designed to investigate antioxidant property and hepatoprotective activity of $P$. chaba roots against paracetamol induced liver damage.

\section{Material and Methods}

\subsection{Chemicals and Reagents}

The assay kits used for biochemical measurements of SGPT, SGOT, ALP and Bilirubin were purchased from Human Gesellschaft for Biochemico and Diagnostica $\mathrm{mbH}$, Germany. Sulphuric acid (Merck, Germany), sodium phosphate (Sigma chemical company, USA), ammonium molybdate (Sigma Chemical Company, USA), ascorbic acid (analytical or reagent grade), methanol (Sigma Chemical Company, USA).

\subsection{Plant Collection and Extraction}

The fresh roots of Piper chaba (Choi) about $5 \mathrm{~kg}$ were collected from Bagerhat district, Bangladesh, in the month of August, 2015 and the plant was authenticated by, Bangladesh National Herbarium (BNH) Mirpur, Dhaka, Bangladesh. A voucher specimen (no. 43198) has been deposited in National Herbarium, Bangladesh. The collected roots were dried and then pulverized into a coarse powder with the help of a grinding machine (FFC-15, China). Powdered plant materials (roots) about $700 \mathrm{gm}$ were soaked in $2.5 \mathrm{~L}$ of ethanol (98\%) for 5 days, then filtered and the filtrate was concentrated under vacuum at $45^{\circ} \mathrm{C}$ by rotary evaporator. This crude ethanol extract of Piper chaba (CEE) was used for evaluating hepatoprotective and antioxidant activities.

\subsection{Paracetamol Induced Hepatotoxicity Model}

\subsubsection{Animals}

Male Wister albino rats six weeks old weighing about (110 - $150 \mathrm{gm})$ (Jahangir Nagar University Animal Research Branch of Pharmacy) and maintained at standard laboratory conditions and fed with commercial pellet diet and normal water. The experiments were performed based on animal ethics guidelines of Institute of Biological Sciences (IBSc), University of Rajshahi, Bangladesh.

\subsubsection{Acute Toxicity Test}

Acute toxicity study was conducted according to the Organization for Economic 
Corporation and Development (OECD) revised Up and Down or staircase method was adopted and accordingly the dose of ethanolic extract (CEE) was calculated [15]. Wister rats were grouped in three groups with four animals in each group and accordingly 175, 550 and $2000 \mathrm{mg} / \mathrm{kg}$ b.w. doses were selected and observed for 14 days for mortality. There was no mortality shown up to a dose $2000 \mathrm{mg} / \mathrm{kg}$, b.w. In this case, $\mathrm{LD}_{50}$ was much more than $2000 \mathrm{mg} / \mathrm{kg}$ b.w. and hence $1 / 5^{\text {th }}$ of the dose was selected. For the present hepatoprotective and antioxidant activity studies, two doses of CEE extracts (200 and $400 \mathrm{mg} / \mathrm{kg}$ b.w.) were selected.

\subsubsection{Experimental Design}

After seven days of acclimatization, the Wister rats are divided into five groups and each group contain, $\mathrm{n}=4$ rats. Two doses of CEE of $P$. chaba (200 and 400 $\mathrm{mg} / \mathrm{kg}$ b.w.) were selected for evaluating the hepatoprotective and antioxidant activities. At this time experimental rats of different groups were weighed and then treatment was done for 7 days. Group I normal controls received only vehicles fed with a normal diet for 7 days. Group II was silymarin plus paracetamol control group received standard drug silymarin $(50 \mathrm{mg} / \mathrm{kg}$ b.w. orally) once a day for 7 days respectively along with the oral administration of paracetamol $(500 \mathrm{mg} / \mathrm{kg}$ b.w. orally) once a day for 7 days. Group III received extract (200 $\mathrm{mg} / \mathrm{kg}$ b.w. orally) once a day for 7 days respectively along with the oral administration of paracetamol (500 mg/kg b.w. orally) once a day for 7 days. Group IV received extract ( $400 \mathrm{mg} / \mathrm{kg}$ b.w. orally) once a day for 7 days respectively along with the oral administration of paracetamol $(500 \mathrm{mg} / \mathrm{kg}$ b.w. orally) once a day for 7 days. Group V was paracetamol control group received paracetamol (500 $\mathrm{mg} / \mathrm{kg}$ b.w. orally) once a day for 7 days.

\subsubsection{Biochemical Studies of Serum}

Different liver marker enzymes were used to perform the liver function tests such as serum glutamic oxaloacetic transaminase (SGOT), serum glutamic pyruvic transaminase (SGPT), serum alkaline phosphatase (ALP) and serum bilirubin were evaluated by standard procedure of diagnostic kits (Human Gesellschaft for Biochemico and Diagnostica mbH, Germany).

\subsubsection{Biochemical Studies of Liver}

Small portion of liver was taken and the tissue were then homogenized separately in $8 \mathrm{~mL}$ of ice cold buffer $(50 \mathrm{mM}$ potassium phosphate buffer $\mathrm{pH} 7.4$ containing $1 \mathrm{mM}$ EDTA) using a Potter-Elvejham homogenizer at $4^{\circ} \mathrm{C}$. Then crude tissue homogenate was then centrifuged at $8000 \mathrm{rpm}$ for $15 \mathrm{~min}$ at $4^{\circ} \mathrm{C}$ and supernatant was removed and kept at $-20^{\circ} \mathrm{C}$ for estimation of reduced superoxide dismutase (SOD), catalase (CAT).

\section{1) SOD assay}

For assessment of hepatic SOD activity accordingly to method of S. Marklund and G. Marklund [16]. $2.8 \mathrm{~mL}$ Tris-EDTA (pH-8.5), $100 \mu \mathrm{l}$ pyrogallol ( $2 \mathrm{mM}$ ) were taken into a cuvette, cuvettee was then inserted into the cell holder and 
scanned for $3 \mathrm{~min}$. Again, $2.8 \mathrm{~mL}$ Tris-EDTA (pH-8.5), $100 \mu \mathrm{l}$ pyrogallol ( $2 \mathrm{mM}$ ) and $50 \mu \mathrm{l}$ tissue homogenate were taken into a cuvette, sample and reagent were mixed gently by inversion, cuvette was then inserted into the cell holder and absorbance was taken at $505 \mathrm{~nm}$. Initial absorbance reading was recorded after 1 minute of incubation and final absorbance reading was recorded exactly after 3 minutes. One unit of SOD is the amount of enzyme that inhibits the rate of auto-oxidation of pyrogallol by $50 \%$. SOD activity was then calculated by the following formula:

$$
\begin{gathered}
\text { Rate }(\mathrm{R})=\frac{\text { Final absorbance }- \text { Initial absorbance }}{3 \mathrm{~min}} \\
\% \text { of inhibition }=\frac{\text { Blank absorption }-\mathrm{R}}{\text { Blank absorption }} \times 100 \\
\text { Enzyme unit }(\mathrm{U})=\frac{\% \text { of inhibition }}{50} \times \text { dilution factor }
\end{gathered}
$$

\section{2) CAT assay}

Catalase activity is measured by the ability of the enzyme to break down $\mathrm{H}_{2} \mathrm{O}_{2}$ based on Aebi's method [17]. The spectrophotometer was set to absorbance with distilled water. Then $50 \mu \mathrm{l}$ tissue homogenate supernatant and $2.9 \mathrm{~mL}$ phosphate buffer ( $\mathrm{pH}-7)$ were taken into a cuvettee. The absorbance was recorded for $2 \mathrm{~min}$ at $240 \mathrm{~nm}$ immediately after adding hydrogen peroxide. Initial absorbance reading was recorded after 1 minute of incubation and final absorbance reading recorded exactly after 2 minutes. Differences between absorbance were calculated. CAT activity was then calculated by the following formula:

$$
\% \text { of inhibition }=\frac{\text { Initial absorbance }- \text { Final absorbance }}{\text { Initial absorbance }} \times 100
$$

\subsubsection{Histopathological Studies}

Histopathological examination was performed for detecting hepatic injuries in liver after treatment of different groups. After sacrificing the rats collected livers were fixed in Bouin's fluid which was saturated in aqueous solution of picric acid $75 \mathrm{~mL}$, formalin (40\%) $25 \mathrm{~mL}$ and glacial acetic acid $5 \mathrm{~mL}$ and after that dehydrated in ascending grades of alcohol with paraffin embedding. Sections were made at $4-5 \mu \mathrm{m}$ and stained with hematoxylin/eosin and examined under lightmicroscope at $100 \times, 200 \times$ and $400 \times$ magnification.

\subsection{In Vitro Antioxidant Assays}

\subsubsection{DPPH Radical Scavenging Assay}

The 1,1-diphenyl-2-picrylhydrazyl radical (DPPH) was used to evaluate the free radical scavenging capacity of the extract according to Choi et al. [18]. $1 \mathrm{~mL}$ methanol solutions of the extract at different concentrations with serial dilution were taken into the test tubes. $2.4 \mathrm{~mL}$ of methanol solution of DPPH was added into each of the test tubes. The test tubes were then incubated at room temperature for 30 minutes in dark place to complete the reaction. Then the absorbance 
of the solutions measured at $517 \mathrm{~nm}$ using a spectrophotometer against blank. The percentage (\%) of inhibition activity was calculated from the following equation:

$$
\% I=\left\{\left(A_{0}-A_{1}\right) / A_{0}\right\} \times 100
$$

$A_{0}$ is the absorbance of the control and $A_{1}$ is the absorbance of the extract/standard (catechin). Then $\%$ of inhibition was plotted against concentration and $\mathrm{IC}_{50}$ was calculated from the graph.

\subsubsection{The Total Antioxidant Capacity}

Total antioxidant capacity of ethanol extract was determined according to Prieto et al. [19] with some modifications. $0.5 \mathrm{~mL}$ solutions of different extractives or standard at different concentrations were taken in the test tubes. $3 \mathrm{~mL}$ of reaction mixtures containing $0.6 \mathrm{M}$ sulphuric acid, $28 \mathrm{mM}$ sodium phosphate and $1 \%$ ammonium molybdate were added into each of the test tubes. The test tubes were incubated at $95^{\circ} \mathrm{C}$ for 10 minutes to complete the reaction. Then absorbance of the solutions measured at $695 \mathrm{~nm}$ using a spectrophotometer against blank after cooling at room temperature. A typical blank solution contained 3 $\mathrm{mL}$ of reaction mixtures and the appropriate volume (300 $\mu \mathrm{l})$ of the same solvent used for the sample and it was incubated under the same conditions as the rest of the samples solution.

\subsection{Statistical Analysis}

The results are expressed as mean \pm SEM using Graph pad prism (version 7). We used a one-way analysis of variance (ANOVA), followed by Scheffe's post-hoc test or students paired or unpaired t-test where appropriate. Results were considered to be significant when $\mathrm{p}$-values were less than $0.05(\mathrm{p}<0.05)$.

\section{Results}

\subsection{Effect of $P$. chaba Root Extract on Biochemical Parameters}

Oral administration of two tested doses of $P$. chaba extract, CEE (200 and 400 $\mathrm{mg} / \mathrm{kg}$ b.w./day) produced changes in all serum biochemical parameters (SGOT, SGPT, ALP and Bilirubin) of liver compared to normal control rats (Table 1). In contrast, rats exposed to paracetamol (500 $\mathrm{mg} / \mathrm{kg}$ b.w./day) induced a severe hepatic damage in serum enzyme activities of SGOT, SGPT, ALP and Bilirubin in comparison to the control group (Table 1). However, co-administration of $P$. chaba extract to paracetamol-induced rats resulted in a partial recovery in the above-mentioned parameters (SGOT, SGPT, ALP and Bilirubin) in a dose dependent manner (Table 1). The low dose of $P$. chaba extract $(200 \mathrm{mg} / \mathrm{kg}$ b.w.) was more effective than high dose $(400 \mathrm{mg} / \mathrm{kg}$ b.w.) to attenuate the perturbations in the tested enzymes.

\subsection{In Vivo Antioxidant Activity by SOD and CAT Assays}

In liver homogenates of paracetamol-treated rats, the SOD $(72.17 \% \pm 8.10 \%)$ and 
CAT $(4.11 \% \pm 0.009 \%)$ level decreased significantly $(\mathrm{p}<0.05)$. Co-administration of CEE of $P$. chaba with paracetamol resulted in a partial recovery in above mentioned parameters in a dose dependent manner. The high dose of $P$. chaba extract $(400 \mathrm{mg} / \mathrm{kg}$ b.w.) was more effective than the low dose $(200 \mathrm{mg} / \mathrm{kg} \mathrm{b.w.)} \mathrm{to}$ reduce the perturbations in antioxidant enzymes (Table 2, Figure 1, Figure 2) and the SOD and CAT level for paracetamol pre-treated high dose $(500 \mathrm{mg}$ paracetamol and $400 \mathrm{mg} / \mathrm{kg}$ b.w. CEE extract) were $61.105 \% \pm 12.14 \%$ and $6.28 \% \pm 0.016 \%$, respectively.

\subsection{In-Vitro Antioxidant Activity}

\subsubsection{DPPH Radical Scavenging Activity}

The scavenging activity of CEE was moderate when compared with standard catechin. CEE extract of $P$. chaba showed promising antioxidant activity in DPPH radical scavenging activity study with increasing concentration (Figure $3(\mathrm{a}))$ and its $\mathrm{IC}_{50}$ value was quite comparable to the $\mathrm{IC}_{50}$ value of well-known antioxidant catechin. The $\mathrm{IC}_{50}$ values of $\mathrm{CEE}$ and standard catechin were $1.563 \pm$

Table 1. Effect CEE of $P$. chaba on serum biochemical level in paracetamol induced rats.

\begin{tabular}{ccccc}
\hline Groups & SGPT & SGOT & SALP & S. bilirubin \\
\hline G I & $41.25 \pm 1.25$ & $55 \pm 2.887$ & $146.75 \pm 3.5$ & $0.125 \pm 0.025$ \\
G II & $52.5 \pm 0.865^{\mathrm{b}}$ & $65.25 \pm 1.89^{\mathrm{c}}$ & $128.75 \pm 6.57^{\mathrm{b}}$ & $0.15 \pm 0.029^{\mathrm{b}}$ \\
G III & $39.25 \pm 1.109^{\mathrm{b}}$ & $70 \pm 2.041^{\mathrm{d}}$ & $151.5 \pm 6.44^{\mathrm{b}}$ & $0.25 \pm 0.029^{\mathrm{d}}$ \\
G IV & $67.5 \pm 1.041^{\mathrm{b}}$ & $75 \pm 2.041^{\mathrm{d}}$ & $176.25 \pm 2.4^{\mathrm{c}}$ & $0.30 \pm 0.041^{\mathrm{d}}$ \\
G V & $77.75 \pm 0.854^{\mathrm{a}}$ & $76.25 \pm 2.40^{\mathrm{a}}$ & $192.5 \pm 4.79^{\mathrm{a}}$ & $0.35 \pm 0.029^{\mathrm{a}}$ \\
\hline
\end{tabular}

GI (Normal control group), GII (Silymarin, $50 \mathrm{mg} \cdot \mathrm{kg}^{-1}$ b.w. plus Paracetamol, $500 \mathrm{mg} / \mathrm{kg}$ b.w.), GIII (Extract $200 \mathrm{mg} / \mathrm{kg}$ b.w. + paracetamol, $500 \mathrm{mg} / \mathrm{kg}$ b.w.), GIV(Extract $400 \mathrm{mg} / \mathrm{kg}$ b.w. + paracetamol, 500 mg/kg b.w.), GV (Paracetamol $500 \mathrm{mg} / \mathrm{kg}$ b.w.) b.w. = Body Weight. Values are expressed as mean \pm SEM (Standard Error in Mean). Significantly different $(\mathrm{p}<0.05)$ was determined (tested by paired t-test). Data analyzed by ANOVA followed by scheffe's post-hoc test. ${ }^{\mathrm{a}} \mathrm{p}<0.05$ in comparison to normal control group, ${ }^{b} \mathrm{p}<0.001$ in comparison to Paracetamol control group, ${ }^{c} \mathrm{p}<0.05$ in comparison to Paracetamol control group, ${ }^{\mathrm{d}} \mathrm{p}>0.05$ in comparison to Paracetamol control group.

Table 2. Effect of $P$. chaba on antioxidant enzyme level (SOD and CAT) in paracetamol induced rats.

\begin{tabular}{ccc}
\hline Groups & SOD (U/mg protein) & CAT (U/mg protein) \\
\hline G I & $103.358 \pm 5.59$ & $17.23 \pm 0.005$ \\
G II & $93.905 \pm 1.64^{\mathrm{b}}$ & $12.79 \pm 0.004^{\mathrm{b}}$ \\
G III & $89.138 \pm 1.109^{\mathrm{b}}$ & $4.75 \pm 0.012^{\mathrm{c}}$ \\
G IV & $61.105 \pm 12.14^{\mathrm{c}}$ & $6.28 \pm 0.016^{\mathrm{c}}$ \\
G V & $72.170 \pm 8.10^{\mathrm{a}}$ & $4.11 \pm 0.009^{\mathrm{a}}$ \\
\hline
\end{tabular}

GI (Normal control group), GII (Silymarin, $50 \mathrm{mg} / \mathrm{kg}$ b.w. plus Paracetamol, $500 \mathrm{mg} / \mathrm{kg}$ b.w.), GIII (Extract $200 \mathrm{mg} / \mathrm{kg}$ b.w. + paracetamol, $500 \mathrm{mg} / \mathrm{kg}$ b.w.), GIV(Extract $400 \mathrm{mg} / \mathrm{kg}$ b.w. + paracetamol, $500 \mathrm{mg} / \mathrm{kg}$ b.w.), GV(Paracetamol $500 \mathrm{mg} / \mathrm{kg}$ b.w.) b.w.= Body Weight. Values are expressed as mean \pm SEM (Standard Error in Mean). Significantly different $(\mathrm{p}<0.05)$ was determined (tested by paired t-test). Data analyzed by ANOVA followed by scheffe's post-hoc test. ${ }^{a} \mathrm{p}<0.05$ in comparison to normal control group, ${ }^{b} \mathrm{p}<0.05$ in comparison to paracetamol control group, ${ }^{c} \mathrm{p}>0.05$ in comparison to paracetamol control group. 


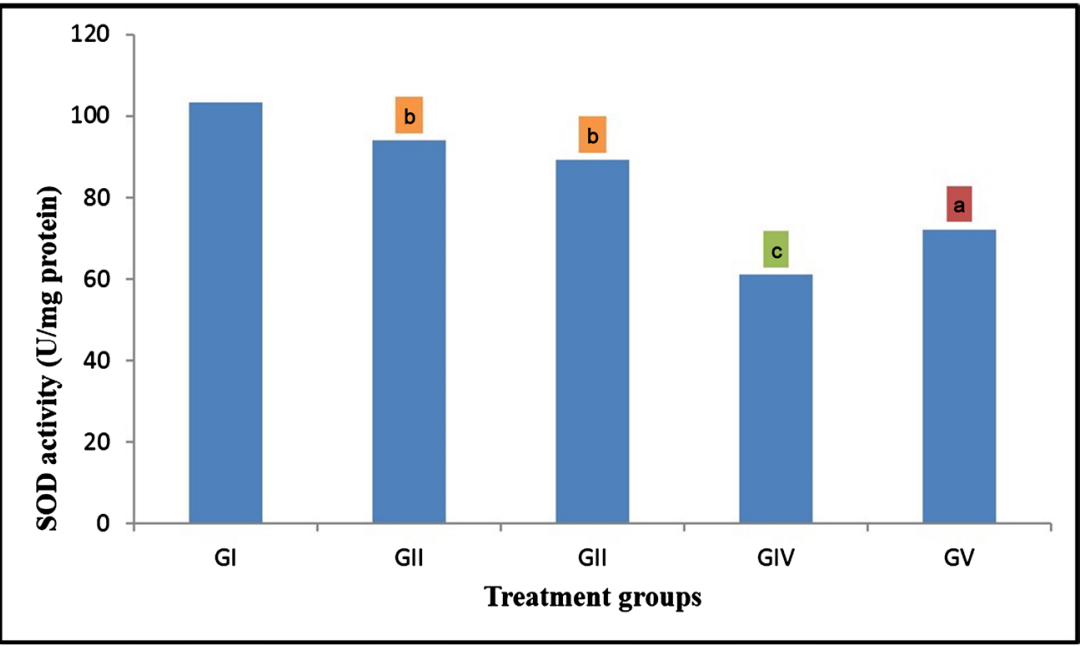

Figure 1. Determination of enzyme unit for SOD activity test of different treatment groups, SOD activity (U/mg protein) was determined in mean \pm SEM. ${ }^{a} \mathrm{p}<0.05$ in comparison to normal control group, ${ }^{b} \mathrm{p}<0.05$ in comparison to paracetamol control group, ${ }^{c} \mathrm{p}>0.05$ in comparison to paracetamol control group.

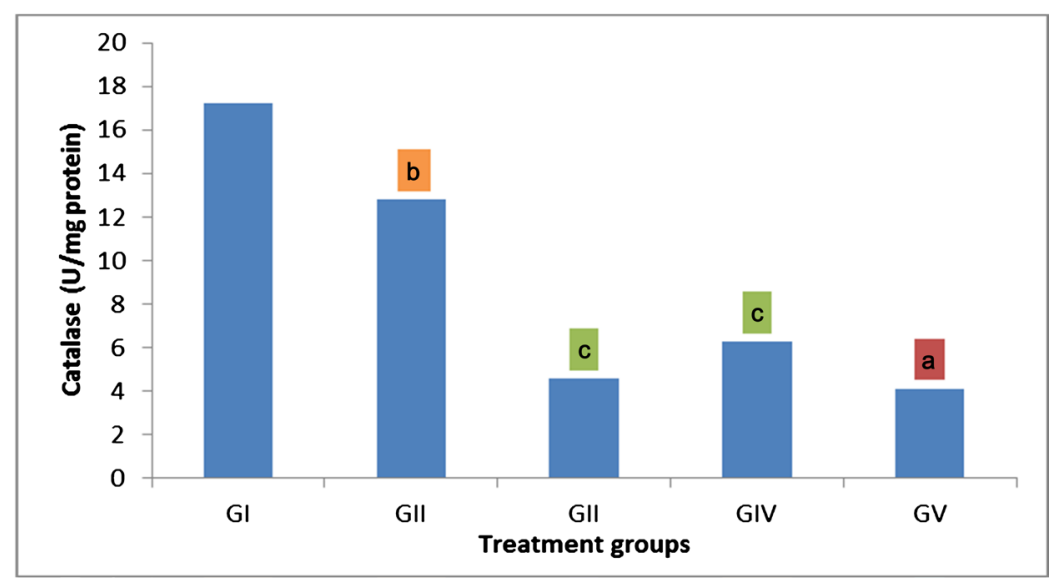

Figure 2. Determination of enzyme unit for CAT activity test of different treatment groups. CAT activity (U/mg protein) was determined in mean \pm SEM. ${ }^{\mathrm{a}} \mathrm{p}<0.05$ in comparison to normal control group, ${ }^{b} \mathrm{p}<0.05$ in comparison to paracetamol control group, ${ }^{c} \mathrm{p}>0.05$ in comparison to paracetamol control group.
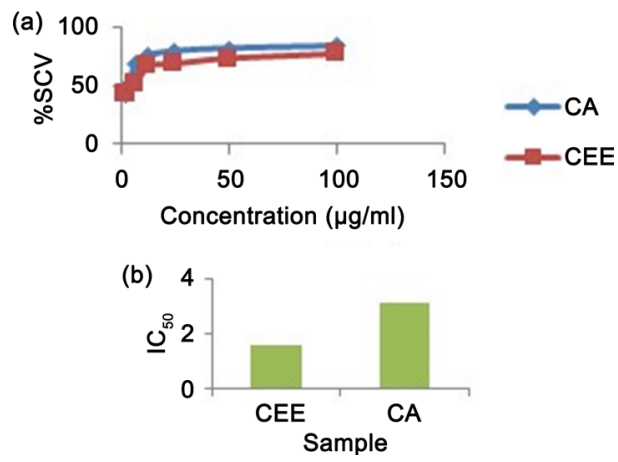

Figure 3. (a) DPPH radical scavenging activity of CEE of $P$. chaba root and CA (catechin) as reference standard; (b) $\mathrm{IC}_{50}$ of CEE and CA (catechin) in DPPH radical scavenging activity assay. 
0.70 and $3.125 \pm 0.676$, respectively (Figure $3(\mathrm{~b})$ ).

\subsubsection{Total Antioxidant Assay}

CEE and standard catechin showed antioxidant activity in a concentration dependent manner (Figure 4). The result revealed that the CEE has promising antioxidant activity as compared to the reference standard catechin and at a concentration of $100 \mu \mathrm{g} / \mathrm{mL}$, the absorbance of CEE and catechin were 0.430 and 0.746 respectively (Figure 4 ).

\subsection{Histopathological Analysis}

The result of light microscopy examination of the transverse section of normal control group showed that normal liver cells in shape with well-preserved cytoplasm, prominent nucleus and clear central vein (CV). Microscopic examination of liver sections from paracetamol treated group showed remarkable disturbance in liver cyto-architecture in comparison to the sections from normal control liver sections (Figure 5(a), (Figure 5(b)). The changes were hepatocyte necrosis, huge amount of fatty cells, several pyknotic cells, huge kupffer cells surrounding central vein, shape change in sinusoids, degenerate nuclei or ballooning degeneration and sever cell infiltration. Liver sections from paracetamol pre-treated group followed by CEE extract at $200 \mathrm{mg} / \mathrm{kg}$ b.w. dose and positive control silymarin exhibited good protection and almost normal cytoarchitecture (Figure 5(c), (Figure 5(d)). However CEE extract at the dose $400 \mathrm{mg} / \mathrm{kg}$ b.w. showed mild to moderate toxicity (e.g. severe cell infiltration, necrosis, sever kupffer cells around central vein, shape change in central vein and blood pooling into central vein) in liver tissues (Figure 5(e)).

\section{Discussion}

Drug-induced liver injury has an estimated annual incidence among 10 to 15 per 10,000 to 100,000 persons exposed to prescription medications [20] [21]. Throughout the development of human culture, natural products has had magical significance and often been the sole means to treat diseases and injuries. During

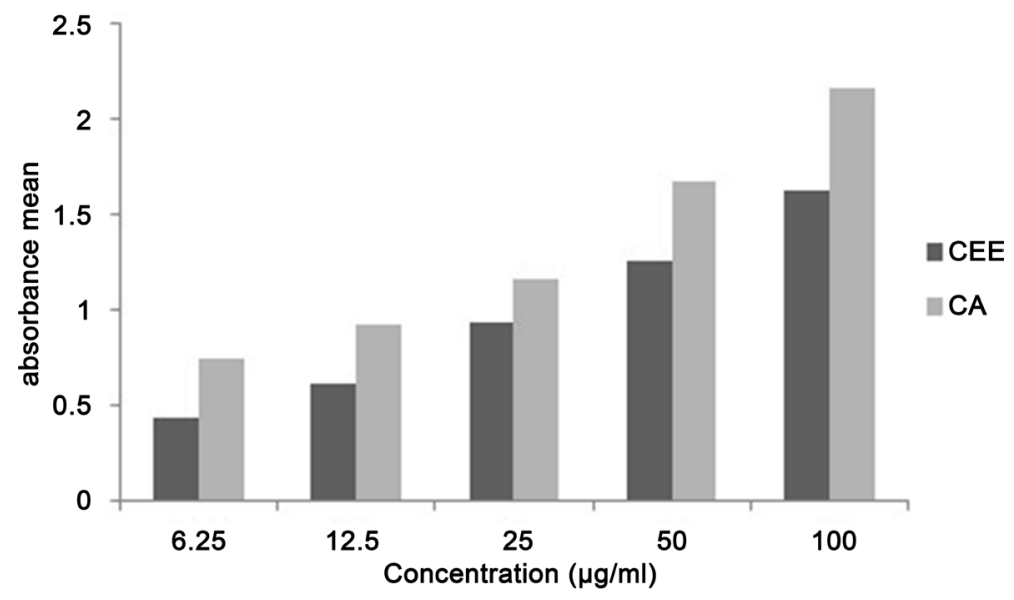

Figure 4. The total antioxidant activity of CEE and standard catechin (CA). 


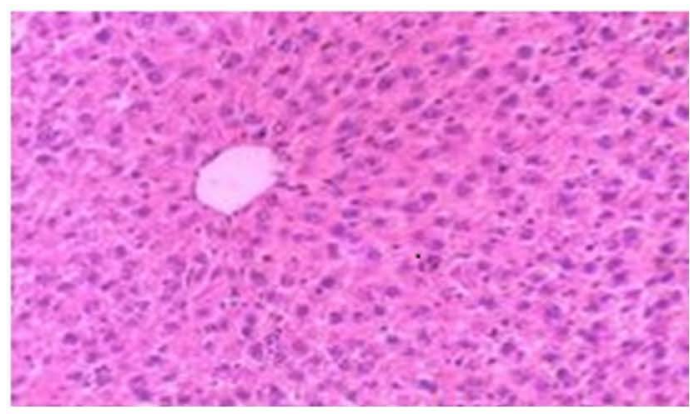

(a)

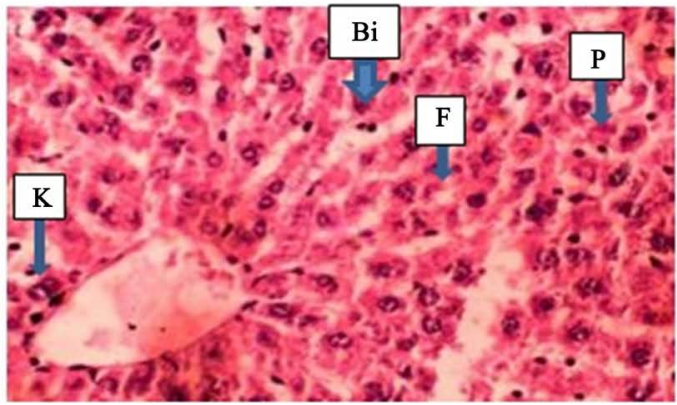

(c)

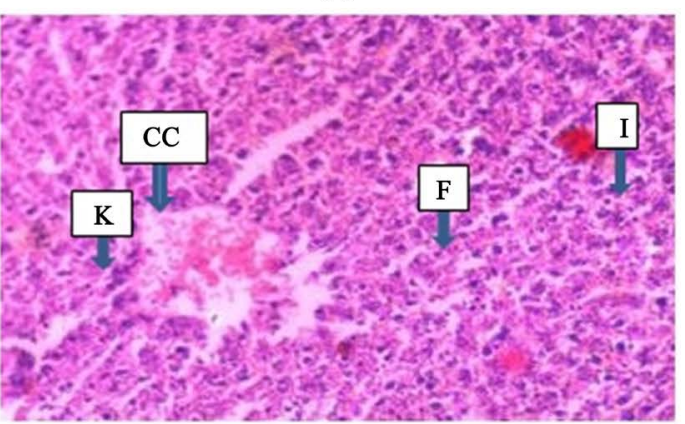

(e)

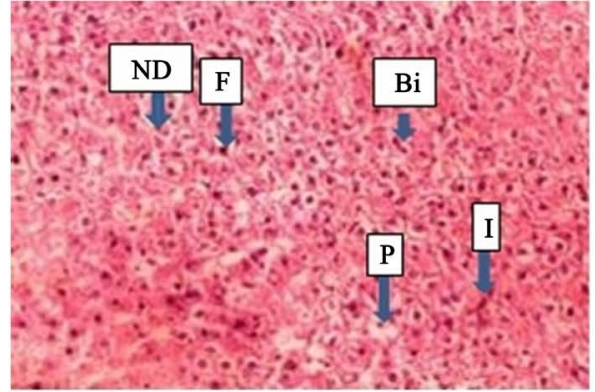

(b)

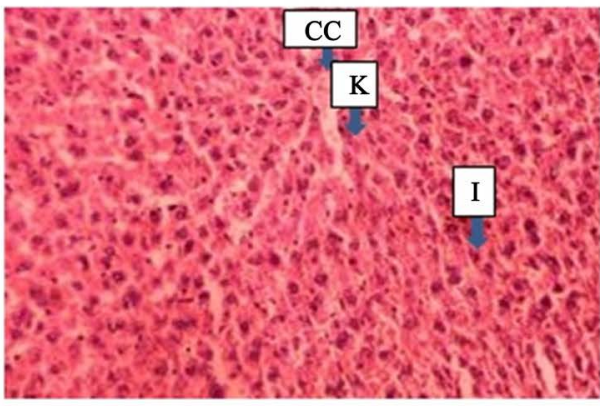

(d)

Figure 5. Photomicrograph of hematoxylin and eosin stained section (200x) of liver of normal and various treatment group rats. Bi (binuclide), CC (change central vein), F (fatty cell), I (inflammatory cell), K (kuffer cell around central vein), ND (degenerate nuclei). (a) Normal Control; (b) Paracetamol Control; (c) Positive Control; (d) Test drug 200 mg/kg b.w. plus Paracetamol; (e) Test drug 400 $\mathrm{mg} / \mathrm{kg}$ b.w. plus Paracetamol.

the past decades, natural products have taken a major role in drug discovery and drug development [22]. In the present study, hepatoprotective and antioxidant activities of Piper chaba roots were carried out on paracetamol induced rats.

Paracetamol induced hepatotoxicity is a commonly used screening method for testing the hepatoprotective potential of plant extracts. Hepatic damage leads to increased serum levels of enzymes like SGPT, SGOT, ALP and bilirubin level etc. [23]. Co-administration of paracetamol and CEE extract of $P$. chaba showed significant reduction in SGPT $(\mathrm{p}<0.001)$ level and ALP $(\mathrm{p}<0.05)$ level at the lower and higher tested dose $(200 \mathrm{mg} / \mathrm{kg}$ b.w. and $400 \mathrm{mg} / \mathrm{kg}$ b.w.) and mild reduction ( $p>0.05$ ) was observed for SGOT and S. bilirubin level. However, only paracetamol (500 mg/kg b.w.) induced a severe hepatic damage to serum enzyme activities (Table 1). Previous studies on $P$. chaba roots showed the pres- 
ence large amount of piperine (9) and the compound piperine is reported to have significant hepatoprotective activity against $\mathrm{CCl}_{4}$ and tert-butyl hydroperoxide induced hepatotoxicity by reducing lipid peroxidation, serum enzymes in the intoxicated mice [24]. The present hepatoprotective activity of CEE could be due to the presence of piperine in $P$. chaba roots.

CEE of $P$. chaba root also showed promising in-vivo antioxidant property $(\mathrm{p}<$ 0.05 ) when compared with paracetamol control group (Table 2) and the \% inhibition of high dose $(400 \mathrm{mg} / \mathrm{kg}$ b.w. CEE and $500 \mathrm{mg}$ paracetamol) group in CAT and SOD activity assay were $6.28 \pm 0.016$ and $61.015 \pm 12.14$, respectively and the $\%$ inhibition of paracetamol treated group $(500 \mathrm{mg})$ in both assays were $4.11 \pm 0.009$ and $72.170 \pm 8.10$, respectively. In DPPH radical scavenging activity assay, the $\mathrm{IC}_{50}$ Value of CEE and standard catechin were 1.563 and 3.125, respectively and \% scavenging was concentration dependent. Total antioxidant assay also supports the antioxidant potential of CEE extract and at concentration of $100 \mu \mathrm{g} / \mathrm{mL}$, the absorbance of CEE and standard catechin were 1.625 and 2.169, respectively. The in-vitro and in-vivo antioxidant activity assay suggest the ability of CEE extract to reduce biological oxidative stress [25]. Hepatoprotective activity of CEE extract may also be acquired by scavenging the free radicals against oxidative stress [26]. Further microscopic examination of liver sections supports the protective effect of CEE extract on liver tissues. Paracetamol treated group showed significant disturbance in liver tissues but paracetamol pre-treated group followed by CEE extract at $200 \mathrm{mg} / \mathrm{kg}$ b.w. dose showed good protection and almost normal cytoarchitecture. However, CEE extract at the dose $400 \mathrm{mg} / \mathrm{kg}$ b.w. showed mild to moderate toxicity (Figure 5(e)) in liver tissues, but proper dose selection can establish the root extract of Piper chaba as a potential lead for hepatoprotective drugs.

\section{Conclusion}

Our present study concluded that the hepatoprotective activity of ethanolic extract of $P$. chaba roots is likely due to its scavenging of free radicals and antioxidant property. It is also possible due to the presence large amount of piperine in the roots. The exact mechanisms of action of hepatoprotection and anti-oxidation activities have not been investigated. Present findings support the traditional medicinal uses of $P$. chaba. By selecting proper dose, the extract of $P$. chaba could be developed as a hepatoprotective and antiaging herbal medicine. Moreover, further bioassay guided isolation of bioactive components may unfold novel hepatoprotective or anti-aging drugs.

\section{Acknowledgements}

The authors thank the Department of Pharmacy, University of Rajshahi, Bangladesh for giving the opportunity to conduct the research work. This project would not have been possible without the financial support provided by Government of Bangladesh in the form of NST (National Science and Technology) 
scholarship to the author Samina Yesmin.

\section{Conflicts of Interest}

The authors declare no conflicts of interest regarding the publication of this paper.

\section{References}

[1] Hawton, K., Beroen, H., Simkin, S., Arensman, E., Cooper, J., Waters, K. and Kapur, N. (2011) Impact of Different Pack Sizes of Paracetamol in the United Kingdom and Ireland on Intentional Overdoses: A Comparative Study Biomed Central. BMC Public Health, 11, 460. https://doi.org/10.1186/1471-2458-11-460

[2] Thomas, S.H.L. (1993) Paracetamol (Acetaminophen) Poisoning. Pharmacology and Therapeutics, 60, 91-120. https://doi.org/10.1016/0163-7258(93)90023-7

[3] van de Straat, R., Vromans, R.M., Bosman, P., de Vries, J. and Vermeulen, N.P. (1988) Cytochrome P-450-Mediated Oxidation of Substrates by Electron-Transfer; Role of Oxygen Radicals and of 1- and 2-Electron Oxidation of Paracetamol. Chemico-Biological Interactions, 64, 267-280. https://doi.org/10.1016/0009-2797(88)90102-0

[4] Adikwu, E. and Deo, O. (2013) Hepatoprotective Effect of Vitamin C (Ascorbic Acid). Pharmacology and Pharmacy, 4, 84-92. https://doi.org/10.4236/pp.2013.41012

[5] Valko, M., Morris, H. and Cronin, M.T. (2005) Metals, Toxicity and Oxidative Stress. Current Medicinal Chemistry, 12, 1161-1208. https://doi.org/10.2174/0929867053764635

[6] Naz, T., Mosaddik, A. and Haque, M.E. (2014) Toxicological Evaluation of a Monoterpene Ester, Bornyl Piperate from Piper chaba Root. International Research Journal of Pharmacy, 5, 12. https://doi.org/10.7897/2230-8407.0512186

[7] Krishnan, M.K.S. (1986) The Useful Plants of India. India: Publication \& Information Directorate, CSIR.

[8] Kirtikar, K.R. and Basu, B.D. (1958) Indigenous Drugs of India. UN and Son's Private Ltd.

[9] Naz, T., Mosaddik, A., Rahman, M.M., Muhammad, I., Haque, M.E. and Cho, S.K. (2012) Antimicrobial, Antileishmanial and Cytotoxic Compounds from Piper chaba. Natural Product Research, 26, 979-986. https://doi.org/10.1080/14786419.2010.535166

[10] Morikawa, T., Matsuda, H., Yamaguchi, I., Pongpiriyadacha, Y. and Yoshika, M. (2004) New Amides and Gastroprotective Constituents from the Fruit of Piper chaba. Planta Medica, 70, 152-159. https://doi.org/10.1055/s-2004-815493

[11] Matsuda, H., Ninomiya, K., Morikawa, T., Yasuda, D., Yamaguchi, I. and Yoshikawa, M. (2008) Protective Effects of Amide Constituents from the Fruit of Piper chaba on D-Galactosamine/TNF-Alpha-Induced Cell Death in Mouse Hepatocytes. Bioorganic and Medicinal Chemistry Letters, 18, 2038-2042.

https://doi.org/10.1016/j.bmcl.2008.01.101

[12] Matsuda, H., Ninomiya, K., Morikawa, T., Yasuda, D., Yamaguchi, I. and Yoshikawa, M. (2009) Hepatoprotective Amide Constituents from the Fruit of Piper chaba: Structural Requirements, Mode of Action, and New Amides. Bioorganic and Medicinal Chemistry Letters, 17, 713-723.

https://doi.org/10.1016/j.bmc.2009.08.050 
[13] Papas, A.M. (1999) Diet and Antioxidant Status. Food and Chemical Toxicology, 37, 999-1007. https://doi.org/10.1016/S0278-6915(99)00088-5

[14] Brown, J.E. and Rice-Evan, C.A. (1998) Luteolin-Rich Artichoke Extract Protects Low Density Lipoprotein from Oxidation in Vitro. Free Radical Research, 29, 247 255. https://doi.org/10.1080/10715769800300281

[15] Shenoy, K.A., Somayaji, S.N. and Bairy, K.L. (2001) Hepatoprotective Effects of Ginkgo biloba against Carbon Tetrachloride Induced Hepatic Injury in Rats. Indian Journal Pharmacology, 33, 260-266.

[16] Marklund, S. and Marklund, G. (1974) Involvement of Superoxide Anion Radical in the Autoxidation of Pyrogallol and a Convenient Assay of Superoxide Dismutase. European Journal of Biochemistry, 47, 469-474. https://doi.org/10.1111/j.1432-1033.1974.tb03714.x

[17] Aebi, H. (1984) Catalase in Vitro. Methods Enzymology, 105, 121-126. https://doi.org/10.1016/S0076-6879(84)05016-3

[18] Choi, H.S., Song, H.S., Ukeda, H. and Sawamura, M. (2000) Radical Scavenging Activities of Citrus Essential Oils and Their Components: Detection Using 1, 1-diphenyl-2-picrylhydrazyl. Journal of Agricultural and Food Chemistry, 48, 41564161. https://doi.org/10.1021/jf000227d

[19] Prieto, P., Pineda, M. and Aguilar, M. (1999) Spectrophotometric Quantitation of Antioxidant Capacity through the Formation of a Phosphomolybdenum Complex: Specific Application to the Determination of Vitamin E. Analytical Biochemistry, 269, 337-341. https://doi.org/10.1006/abio.1999.4019

[20] Sgro, C., Clinard, F., Ouazir, K., Chanay, H., Allard, C., Guilleminet, C., Lenoir, C., Lemoine, A. and Hillon, P. (2002) Incidence of Drug-Induced Hepatic Injuries: A French Population-Based Study. Hepatology, 36, 451. https://doi.org/10.1053/jhep.2002.34857

[21] Bjornsson, E.S., Bergmann, O.M., Bjornsson, H.K., Kvaran, R.B. and Olafsson, S. (2013) Incidence, Presentation, and Outcomes in Patients with Drug-Induced Liver Injury in the General Population of Iceland. Gastroenterology, 144, 1419. https://doi.org/10.1053/j.gastro.2013.02.006

[22] Ji, H.F., Li, X.J. and Zhang, H.Y. (2009) Natural Products and Drug Discovery. Can Thousands of Years of Ancient Medical Knowledge Lead Us to New and Powerful Drug Combinations in the Fight against Cancer and Dementia? EMBO Reports, 10, 194-200. https://doi.org/10.1038/embor.2009.12

[23] Drotman, R.B. and Lawhorn, G.T. (1978) Serum Enzymes as Indicators of Chemical Induced Liver Damage. Drug and Chemical Toxicology, 1, 163-171. https://doi.org/10.3109/01480547809034433

[24] Koul, I.B. and Kapil, A. (1993) Evaluation of the Liver Protective Potential of Piperine, an Active Principle of Black and Long Peppers. Planta Medica, 59, 413-417. https://doi.org/10.1055/s-2006-959721

[25] Madhukiran, P., Raju, A.V. and Ganga Rao, B. (2012) Investigation of Hepatoprotective Activity of Cyathea gigantea (wall. Ex hook.) Leaves against Paracetamol-Induced Hepatotoxicity in Rats. Asian Pacific Journal of Tropical Biomedicine, 2, 352 356. https://doi.org/10.1016/S2221-1691(12)60055-0

[26] Ravikumar, S. and Gnanadesigan, M. (2011) Hepatoprotective and Antioxidant Activity of a Mangrove Plant Lumnitzera racemosa. Asian Pacific Journal of Tropical Biomedicine, 1, 348-352. https://doi.org/10.1016/S2221-1691(11)60078-6 


\section{Abbreviations}

SGOT Serum Glutamic Oxaloacetic Transaminase

SGPT Serum Glutamic Pyruvic Transaminase

ALP Alkaline Phosphatase

SOD Superoxide Dismutase

CAT Catalase

CEE Crude Ethanolic Extract

b.w. Body Weight 